\title{
Interpretation of The Legal Values and Justice in The Living Law Related To Court Decision
}

\author{
Ismail Rumadan \\ Center for Research and Development of Law and Justice \\ Supreme Court of the Republic of Indonesia \\ ismailrdhan@gmail.com
}

Published: 25/02/2021

How to cite:

Rumadan, I. 2021. Interpretation of The Legal Values and Justice in The Living Law Related To Court Decision. Sociological Jurisprudence Journal. Volume 4 Issue 1. Page 13 - 22. https://doi.org/10.22225/scj.4.1.2946.13-22

\begin{abstract}
The performance of judges in deciding on a legal dispute that is faced is a work process looking for legal norms both in the legislation and legal norms that live in the community. Based on the results of the above studies it can be concluded that; at the practical level there are two approach models used by judges to examine and adjudicate a civil case related to the values and rules of customary law in society, namely an evolutionist approach which holds the view that indigenous peoples are a community with barriers in the process of integration into the modern world, so that this transition process must be guarded through legal procedures. This view has an effect on the pattern of approaches used in dealing with a case related to customary issues and norms living in the community, this approach in view of the formalistic legal approach influenced by the possibility of legism-positivism, so that in some cases the disputed adat the right to customary land in Papu the judge always put forward formal proof of ownership of letters explaining proof of ownership of a plot of land, so that many customary civil cases must be rejected by the Court because the Plaintiff or the defendant can not prove formally proof of ownership over the disputed land.
\end{abstract}

Keywords: Law and Justice Values, Society, judge's decision

\section{INTRODUCTION}

The performance of judges in deciding on a legal dispute that is faced is a work process looking for legal norms both in the legislation and legal norms that live in the community. Judges are required to be able to resolve a legal dispute that is faced without a reason to reject a reason that the law does not regulate it. If in the absence of a positive legal norm or positive legal norm does not clearly regulate the problem related to what is faced by the judge, then the judge as the implementation of the law, must explore, follow and understand the legal and racial values that live in society.

The above statement as stated concretely in the provisions of Article 5 paragraph (1) of Law Number 48 of 2009 concerning Judicial Power that:

"Judges and constitutional justices are obliged to explore, follow and understand the legal values and sense of justice that lives in society".

Formulating the provisions above is certainly based on the fact that judges in examining and deciding cases often face a situation, where the written law is apparently not always able to solve the problems faced by the dynamics of the law that always develops along with the development of people's lives, so it is almost certain, the law ( written) always lags behind the dynamics of society. Based on this fact, it is not wrong if various theories emerge that oppose the flow of positivism.

Indonesia as a former Dutch colony that adheres to the civil law system, the legal system is strongly influenced by the system, so that the flow of legism-positivism still exists in practice, although 
admittedly in recent years it has experienced a slight shift towards the common law system. As a result of the persistence of this understanding, it is often found the attitude of judges who are juridicaldogmatic and only act as mouthpieces of the law "(buche de laloi), without considering the valuesvalues living in society. As a result, many of the judges' decisions were publicly condemned because they could not fulfill the community's sense of justice.

Every society always has a culture that is an individual characteristic of its members collectively, one of which is a legal culture that is an understanding of norms or values that live in everyday life, both written and unwritten, so that people's lives run in an orderly manner and move according to rules, be creative and create civilization ${ }^{\mathrm{P}}$.

This paper wants to examine how the judge's approach in understanding and interpreting the values that live in the community against disputes that intersect with the needs of the local indigenous community? Likewise, to the parties as well as to the object of the dispute related to traditional values and crocodiles that live in the community?

\section{DISCUSSION}

\section{Law and Society}

Law and society are two inseparable phenomena. Law is a social institution, meaning law is a unity of kaedah-kaedah which aims to meet basic human needs at all levels, which aims to achieve peace in society. Soerjono Soekanto, argues law is a very important phenomenon because it becomes the basis of legislation and the legality of various other social phenomena that also become social institutions. Thus, law as a social institution not only creates order for other social institutions, but also creates its own values, principles, and rules. The existence of these values, principles, and norms leads to the emergence of certain role mechanisms and positions. Therefore, the law is not merely a secure force, but also a force that creates the facility to simplify and facilitate the process of social interaction ${ }^{2}$.

The law in its function as legalization, means to validate the existing symptoms in society, so that legislation is a means for social control, while the law in its function as a tool of legislation is a process of reformation, so that the legislation can always be applied according to the condition of society faced. Riduan Syahrani states, rules of law apply or live in society, if the method has four elements that must be met namely ${ }^{3}$ :

The rule is known;

The rule is appreciated;

It is adhered to;

The rules are recognized

The process of cultivation (noumering process) of the four elements is the first step to find out whether a rule really lives in society. Success or not pengkaidahan highly depends on three factors, namely:

The effectiveness of planting these rules in the community;

Reactions and responses arising from the community, and

The speed of instilling rules in society ${ }^{4}$.

The process of the birth of the rule of law is sometimes created by lawmakers and sometimes born from other social norms (moral principles, norms of decency and religion). Against this second form by Paul Bohannan, as quoted by Ahmad $\mathrm{Ali}^{5}$, called the rule of law derived from the process of double legitimacy or legitimasi. Both the norms of law, religious norms, morality norms, and norms of decency contain answers to questions, what should / should be done by people as members of society.

The difference is only gradual in which propriety increases to one level, and how the government especially the judges do for the benefit of society should pay attention to the norm, that's where it can be said that the norm in society is the legal norm. To what extent a norm must be binding so that the government and the court must pay attention to the norm. Wirjono (1974: 14) states, that should be considered is the purpose of the law that is for the safety and order of society. Public salvation means the 
salvation of all those who are members of society. Thus, the size of which is the legal objective of public order and safety.

It can be concluded that, if a norm in society is concerned with safety and / or order, where violations of the norm have disturbed the joints of public order and safety, then the norm has increased at one level.

\section{Obligations of Judges Explore and Understand the Values of the Living Law in the Community}

The dynamics of development and social change take place so rapidly and continuously that it is able to prove the limitations of lawmakers in anticipating and predicting precisely the direction and tendency of social change. Meanwhile, legal reform through the legislation process, in order to adjust to the reality of social change itself, does not run fast as expected, it is experiencing various obstacles, inaction, and even can be said stagnant. It is therefore quite difficult to expect legal reform through the legislation process ${ }^{6}$.

The court has an important position and role in legal reform. Applicable adagium that the judge is considered to know about his law (ius curia novit) from the case submitted to him. Therefore, the Law on Judicial Power affirms that the Court should not refuse to adjudicate cases by reason of unclear law or non-regulating law. The court is obliged to examine, hear and give judgments on every case submitted to it.

The meaning and consequence of the provision is so serious that the judge's figure must have a deep and wide knowledge of and insight about the law, including the most recent laws. Therefore, the judge's figure should never stop learning but continually have to update his knowledge and understanding of the law and its dynamics. In addition, the law referred to in the adage is not a law in the narrow sense that is only limited as a law, but the law in its broad meaning, including the value of justice and law that live in society.

Judges who are mythologically perceived as "God's representative in the world" are believed to be able and wise in using their authority to examine and decide cases in accordance with law and justice. In such a situation it becomes very relevant to discuss the role of the judge as a reformer of the law.

The role of a mutatis mutandis law reformer applies to all judges. As a reformer of the law, judges have the authority to engage in so-called judicial activism, which includes rechts interpretation, legal construction (rechtsconstructie), legal discovery (rechtsvinding), legal formation (rechtsvorming), as well as legal creation (rechtsschepping) ${ }^{7}$. Through its decision, it is expected to be able to be active and progressive role in reforming the law. Judges fill the legal void through the use of instruments and methods of interpretation of the textual formulation of a legislation. There are various interpretation options that the judge can use to find the law as the basis of his decision. The judge has the freedom to choose and use the interpretation in accordance with the needs and contextuality of the case in hand. But freedom of choice and use of interpretation is not merely about the taste, but rather the selection and use of appropriate instruments and methods to achieve the right goal. It would therefore be very possible for the diversity of elections and the use of interpretations among judges even though examining and adjudicating the same or similar subject matter. It depends on the contextuality of each case.

The use of interpretive instruments and methods is very useful, not only in the context of legal discovery, but also for the development and renewal of the law. The textual formulation of a law is generally made in accordance with the agreement of the legislators of his day. Whereas the formulation of "words" or "phrases" in the text of a law, always has the limitation of the ability to reflect comprehensively on the will and the ideals of the makers and the anticipation of the dynamics of the development of the social reality it regulates. A progressive, futuristic-anticipative interpretation may be a correction of the substance of the existing norm of ius constitutum and contribute in the formulation of norms ius constituendum ${ }^{8}$.

The judge may also re-interpret the pre-existing interpretation, it is intended to re-actualize and revitalize the meaning of the textual formulation of a legislation. Thus there is no interpretation that is permanent and applies equally forever. Except for authentic interpretations that are deliberately made by the legislator as a form of official explanation of a terminology or textual formulation contained in the law.

The judge in examining, hearing and deciding a case, must first use the Written Law as the basis of 
his decision. If the written law is insufficient, it is not appropriate with the problem in a case, then the judge seeks and finds his own law from other sources of law such as jurisprudence, doctrine, tractate, custom or unwritten law. Law no. Article 10 Paragraph (1) of Judicial Power determines "that the Court is prohibited from refusing to examine, hear, decide upon a case filed with legal argument absent or less clear, but obliged to examine and prosecute". The provision of this article gives the meaning that the judge as the main organ of the Court and as the executor of the judicial power shall be required by the Judge to find its law in a case even though its legal provisions are absent or less clear.

Article 5 (1) of Law No. 48 of 2009 on Judicial Power also explains that "Constitutional Justices and Judges shall multiply, follow and understand the legal values and sense of justice living in the community". The word "digging" usually means that the law already exists, in the rule of law but is still vague, difficult to apply in concrete cases, so to find its laws should seek to dig by the values of living law in society. If you have found the law in the excavation, then the Judge must follow it and understand it and make the basis of the decision to fit the sense of justice that lives in society.

In another sense related to the authority and duties of the judges in digging and understanding the law and justice living in the community meant that the judges were able to understand the values of law and sense of justice living in the community. A judge must always be present, involve, and be to-be in the midst of real social life, without having to fear or worry about losing his or her identity as a judge who must remain objective, fair, independent and impartial. To maintain its impartiality and independence. That although the profession of judges is often interpreted as a silent profession but it should not be interpreted that a judge must alienate himself, or imprison himself, and leave his social life.

In the practice of the Court, there are 3 (three) terms often used by the Judge in examining, adjudicating and deciding a civil case, the judge is confronted with several terms that must be done by the judge namely the invention of law, the establishment of law or creating law and the application of law. Among these three terms, the term law discovery is most often used by Judges, while the term law formation is usually used by the legislating body (DPR).

The task of finding the law against a matter being examined by the Panel of Judges is the most difficult thing to do. Although judges are considered to know the law (ius curianovit), in fact the judges do not know all the laws, because the law is various kinds, some are written and some are not written. But the Judge must properly adjudicate the case brought to him, he should not refuse a case for reasons of the law is absent or unclear, but he is obliged to try him. As a law enforcer he must dig, follow and understand the value of the living law in society. The judge in adjudicating a case submitted to him must be clear about the facts and events in the case.

According to Abdul Manan ${ }^{9}$, take the judges in the construction of the discovery and solving legal problems, must know the three main requirements are:

construction should be able to cover all areas of positive law in question,

in the construction there should be no logical contradictions in it,

construction presumably contains a factor of beauty in the sense of not artificial, but with the construction of problems that are not yet clear in the rules. is expected to appear clarity.

Construction should be able to give a clear picture of something, therefore it should be simple enough and not cause new problems and should not be implemented. While the purpose of the construction is for the judge's verdict in concrete events to meet the demands of justice and beneficial to the justice seeker ${ }^{10}$.

Even under certain conditions, the judge is faced with the legalistic stiffness of legal rules, the judge is required to be able to get out of the legislative nature of law by developing a new construction pattern against a legal problem faced. Positivistic mindset judges need to be rebuilt or developed into more progressive arenas in solving legal problems faced amid increasingly diverse and complex societies.

Understanding of legal positivism makes the rule as the reference and the only source in prosecuting a lawsuit. The judge is only positioned as a mouthpiece of the law and may apply the law mechanically and procedurally. The rule of law is placed as center and purpose in itself, regardless of other 
dimensions beyond the rules, the values of indigenous knowledge and norms and honesty are neglected. As a result, the sensitivity, empathy, and dedication to bring justice and truth lags far behind. Justice and truth are mere formal legal issues ${ }^{11}$.

The strong way of thinking legal positivism among judges makes the main cause of the law is not able to understand and nurture the values of local wisdom that became the legal basis rooted in the community. Therefore, there needs to be a breakthrough of new piker patterns that are more progressive by the judges in solving legal problems in the midst of a more wise and adequate society. In a word, there is a paradigm shift from the legal positivism paradigm to the progressive legal paradigm. The use of progressive methods of legal interpretation is intended to allow judges to place a legal interest for human beings rather than on the contrary that human beings are forced to submit to the rule of law. progressive interpretation is an interpretation that puts human behavior through established legal norms that put more emphasis on justice more intrinsically ${ }^{12}$.

The progressive use of progressive interpretive motives can be found in some judges' decisions, for example in the case of a parenting dispute (haḍānah) in a Supreme Court ruling. 349K / AG / 2006 dated January 3, 2007 on the case of divorce between Tamara Blezynski and Teuku Rafly Pasya which is one of the object of his dispute concerning the rights of child care both named Rassya Islamay Pasya. The case seized the public's attention, not only because it involved the artist's divorce, but which attracted the Supreme Court to break the case unusually. Discussions sprang up, especially those that questioned the juridical foundation of the Supreme Court's ruling that seemed to contradict the provisions of childcare in the Compilation of Islamic Law (KHI).

It can be understood that, ideally in the context of childcare cases can not be separated from the rules on which it is based. KHI Section 105 states in the event of a divorce:

Maintenance of children who have not mumayyiz or not yet 12 years old is the right of his mother;

Maintenance of a mumayyiz child shall be left to the child to choose between his father or mother as the holder of his right of maintenance;

Maintenance costs borne by his father.

The above provision implicitly indicates that KHI and Law no. 3 Year 2006 is still global, so it has not given a definitive solution of juvenile juridical issues when both parents divorced. Except to the provisions of KHI Article 105, KHI Article 156 states that due to the marriage breakup due to a divorce:

Unaccompanied children are entitled to get haḍānah from their mother, except when her mother has died, her position is replaced by: a) women in a straight line up from mother; b) the father; c) women in the upright line of the father; d) sister of the child in question, and e) women of the blood relatives by the side line of the father;

\section{Mumayyiz's child is entitled to choose haḍānah from his father or mother;}

Where the holder of hadānah can not guarantee the child's physical and spiritual salvation, even though the cost of living and hadạnah has been satisfied, then at the request of the relative concerned the Religious Courts may transfer the right of haḍānah to other relatives having the right of hadānah as well;

From the above description it can be concluded that KHI Section 105 specifies parenting in two circumstances: First, the child has not mumayyiz (not yet 12 years of age) the child's care is in his mother. Second, the child is mumayyiz (age 12 years and over) submitted to the child to choose between his father or mother to take care of him. While KHI Section 156 regulates the care of the child when her biological mother dies, by assigning parental rights to the family in sequence. In addition Article 156 letter c states that childcare rights may be void if the holder of haḍānah can not guarantee the child's physical and spiritual salvation, which in turn the PA may transfer the right of hadāanah to other relatives who have hạāanah right. UU no. 3 of 2006 does not provide meaningful arrangements on childcare.

The Supreme Court ruling relating to the divorce dispute, one of its decisions, stipulates that the child is in the care of his father, whereas the child is still under 12 years of age. The Supreme Court on another ruling establishes the care of the child to his father because of the apostate's wife to his original religion. From the Supreme Court decision No. 210K / AG / 1996 can be concluded that the issue of 
religion is an absolute requirement in determining parenting rights for mothers of unaccompanied children $^{13}$. According to Syamsuhadi Irsyad, the Supreme Court's decision on childcare that sets out to the father is based on consideration of the safety of the child's aqidah ${ }^{14}$.

When considering the decision of the Supreme Court, there appears to be a strong orientation of the ruling by basing on the objective of legal formation in the jurisprudence perspective referred to as maqāsid al-shar'iyyah who wishes to put justice in the portion, that the guarding of aqidah is a condition to determine the decline of a mother's right over the care of his unmumayyiz child.

\section{Application of Legal and Justice Values that live in Society as the basis of Judges' Consideration in Tribunal Civil Proceedings}

The judicial glove is an extension of the objective of the formation of the law, namely as a tool for determining justice. The legal realism group pioneered by Oliver Wendell Holmes even sees that law is what the judiciary makes by means of judgment (the prophecies of what the court does) ${ }^{15}$. Similarly Karl Llewellyn reveals that: "what officials do about disputes ${ }^{16}$." In the viewpoint of the flow of Law Anthropology pioneered by Schapera which states "law is any rule of conduct likely to be enforced by the courts" (law is any rules of conduct that may be held by the courts) ${ }^{17}$.

The growing legal paradigm shows the hope that the courts, especially judges, are not only able to provide procedural justice pursuant to the text of legislation, but more important is justice of suntansif. Substantive justice does not mean that judges should always ignore the sound of the law but with substantive justice means the judge can ignore the law, which does not impose a sense of justice, but is guided by a formal law that already gives a sense of justice while ensuring legal certainty.

In a sociological perspective, substantive justice can be realized if a judge is able to punish by leapfrog over tasks and powers conferred by formal rules texts ${ }^{18}$. The effort to fulfill the sense of justice depends on how a judge uses approaches to the concept of justice in deciding a case ${ }^{19}$.

Therefore, the judge needs to develop a sociological approach in understanding a legal issue related to the public interest. This sociological approach is important to see the law as a building of the morma that must be understood by meanganilising the text or the sound of written laws or rules ${ }^{20}$.

This sociological approach is more to see the law as a social building (social institution) that can not be separated from other social buildings. Law is not understood as a text in written or written law but as a social reality that affects life. Law is not understood textually normatively but contextually. In line with that, the approach of law is not only based on just legal logic but also with social logic in order to seaching for the meaning. This approach is expected to explain the various legal phenomena that exist through the tools of the logic of the social sciences. Various legal practices that are inconsistent with normative rules, legal disparities, the occurrence of deviant behavior, anomaly of law, disobedience, lawlessness, violent, criminalism and so on will be more easily explained through this approach ${ }^{21}$.

The judge's approach to this context still refers to a philosophical, normative, and empirical approach. The context of this approach is similar to the previous approach:

The approach of morality, whose focal concern is the moral basis of law and its legal validity is the consistency of law with external ethics or moral values.

The jurisprudential approach (legal jurisprudence) whose focal concern is the legal inden- tence and its validity is the internal consistency of the law with the rules, norms and principles of the law itself.

The sociological approach, the focal concern of law and social action, where its legal validity is the legal consequences for its people.

In the context of this study, in general the most appropriate approach to use in the context of understanding the reality of the legal values living in a society is a sociological approach, this approach is able to lay the legal issue in accordance with the structure and strata of social life in society.

\section{Application of Bright Principle, Helpfulness, and Kinship in Cases of Waris Gondok}


Decision of Bantul District Court Number 20 / Pdt.G / 2009 / PN.Btl regarding the status of heritage land gandok. The judge's verdict in the case is rejected / not accepted so that the defendants remain as owners of the land of gandok. The basis of the judge's consideration in the verdict is that the proof of the status of the gandok land does not meet the bright principles because the plaintiffs can not prove that the status of the gandok land has been witnessed by the village government, the principle of kinship is also not fulfilled by the plaintiff because the payment of land and building taxes should be borne jointly between the plaintiff and the defendant but in such cases is only paid by the defendant himself.

The basis of judges' consideration is that protection is a legal act governed by customary law based on the principle of help, especially in Yogyakarta. The protector helps the landowner by helping to alleviate the work of the landowner. While the landowner helps the protection by allowing the protector to build a house on his land which is not based on rent but based on the principle of kinship and help.

\section{Application of the Principle of Decisiveness in the Mind}

The Decision of the Yogyakarta District Court Number 31 / Pdt.G / 2009 / PN.Yk on the indung and the judicial right courts apply the principle of propriety. The basis of judges' consideration in deciding the case is the principle of law there is a form of propriety. In the jurisprudence of the Supreme Court Nomo 756K / Sip / 1973 dated 13-5-1975 it is explained that the right of protection does not automatically descend to the heirs of the chamber without any new deal agreement. It is therefore fitting that the defendant should leave the house at his own expense without severance pay because the house stands on the plaintiff's land. The jurisprudence of the Supreme Court Number 1051K / Sip / 1974 dated 12-2-1976 also stipulates that the implementation of the decree in the form of dismantling, it is necessary to be careful that in the future there will be no dispute.

\section{Application of customary law norms in Joint Treasury Case (gono-gini)}

Case of divorce between Purwadi and Ariani based on Religious Court decision of Yogyakarta Number 181 / Pdt.G / 1998 / PA. Yogyakarta dated November 11, 1998 which has fixed law, but in that case excludes the division of marriage property. Case of divesting of marriage property due to divorce decided by the judge of Yogyakarta District Court Number 105 / Pdt.G / 2000 / PN.YK. Judge decide the case by basing themselves on the customary law norms that if there is divorce, the joint property (gono gini) is divided between husband and wife divorced.

The panel of judges decided that according to the norm of customary law the division of joint property in marriage was divided between husband and wife, each of which received $50 \%$. So $1 / 2$ part of the total price of the house $(25,000,000$, -) for the husband part, while $1 / 2$ part of the amount of home property $(25.000 .000,-)$ for the wife. The decision of the judge of the Yogyakarta District Court is based on the Supreme Court Decision Number 1373K / pdt / 2002 that the property acquired during the marriage, according to the customary law norm becomes the common property of the husband and wife. According to customary law norms, the division of marriage property in the event of divorce, both parties take back their respective goods plus the property of each part in the joint treasure. Supreme Court jurisprudence number 120K / Sip / 1959 stipulates that due to the growth of civil law in High cliff area it is appropriate that the joint property after divorce for Bojonegoro region also apply that in the event of divorce, the gono gini is divided by husband and wife who each get half.

\section{Implementation of Legal Norms Release of Customary Rights in Transaction of Sale and purchase of customary land}

Furthermore, in the High Court of Jayapura Decision Number 53 / Pdt / 2014 / PT JAP, the sale and purchase of land in Jayapura must be preceded by the release of customary rights. The verdict canceled the Sale and Purchase transaction of land controlled by the Jayapura Provincial Government for the purpose of the construction of KODAM XVII was canceled by the court because the defendant's act was lawfully committing the act against the law since the sale took place prior to the release of the Customary Land Rights and compensation of the customary land is a customary norm that lives in the middle of Papuan society in general.

The act is also an act that is deemed to be contrary to the Special Autonomy Law (Otsus) that the 
Provincial Government of Papua should provide protection for indigenous Papuans, in particular the customary rights of the Plaintiff never existed, and even the Defendant continuously neglects the rights custom of the Plaintiff.

The judges' considerations in the above decisions are very appreciative of indigenous wisdom and local legal norms so that it is highly appreciated because the judges are right in deciding the dispute by considering the continuity of customary law community and customary norms that are still alive in the community.

Due to the Law of Deviation of Sale and Purchase of Land of Ulayat Rights and Registration of Certificate as a Proof of Right in Papua Certificate as a Strong Evidence Tool One of the most important in court in court, whether civil case, criminal and state administration is related to proof.

Whoever claims to have rights, or who deny / add to him must prove the existence of such right or event, this is explicitly stipulated in Article 1865 of the Civil Code. In daily practice relating to the use of land title certificates as evidence in the form of letters, the assessment is inseparable from two aspects of the assessment namely; regarding formal truths such as the publication of certificates with the process and material truths concerning the content of the land title certificate and the description of the origin of the owner.

In principle the burden of proof in court is the same, both civil cases, criminal and administrative state. In Government Regulation No. 24 of 1997 provides legal guarantees to holders of land rights, that as long as it has not been proven otherwise, the certificate of land rights is the only means of verifying land ownership and must be accepted as true data, both in the daily legal deeds as well as in dispute in the Court. The strength of the evidence in the practice of the courts may vary, such as the usual evidence in this case the deed is under hand, full proof of notarial deed and certificate of title to the land and there is also evidence of coercive nature such as the Certificate of Mortgage Rights, Auction and Decision Peace.

The strength of evidence and assurance of certainty and legal protection of land titles certificate, can be seen from the process of registration of land and the resulting certificate. In the science of production note that the resulting output comes from the input obtained and then processed. This can be equated in land registration activities. At the Land Office, the inputs obtained from the landowners applying for the certificate are then processed through land registration so as to produce physical data and juridical data described in the land measurements and books and then issued the certificate as a quote from a land and measuring book and stitched together In the above frame of mind, can be analyzed what guarantee can be given from the process or the result of land registration activity at the Land Office. To facilitate understanding can be grouped, that for physical data is called guarantee of right certainty while for juridical data is called guarantee of legal certainty.

This grouping can be seen that physical data as a result of physical cadastre such as measurement, mapping, examination by Committee A and so on, with it all can be ascertained where the location, boundary and area and who the right holder. While the juridical data as a result of the cadastral legal such as the making of a land book, the provision of proof of certificate of right of certificate, transition han and so forth.

Land dispute cases settled through courts Settlement of land dispute conflicts can be resolved through deliberation, but others end up being resolved through court proceedings. Below are examples of land cases that have been decided through a court decision that has had a permanent legal force (inkracht van gewijsde). Supreme Court Reg. 2057 K / Pdt / 2006 civil case between Hengki Darwin Tobatdji Enj'ros tribe chief with Handoyo Tjondro Kusumo. Disputes, conflicts and land issues and reporting on conflict handling and resolution, land disputes and cases. In solving the problem if the deliberation is not resolved then the party to the dispute is advised to submit it to the court.

Although the main factor of such conflicts is clear, some customary law experts divide into three factors:

The Government does not expressly define and determine the status of ulayat land in the national legal system, especially in the Basic Agrarian Law no. 5 years 1960,

The Government has even denied or at least dwarfed the enforceability and implementation of 
customary land rights owned by local residents. This is particularly evident in the basic forestry law no. 5 years 1967, hereinafter referred to as UUPK 1967, with PP no. 21/1970, 3. and Decree of the Minister of Forestry no. 251 / Kepres-II / 1993.99.

Legal awareness of the settlement of land cases during the reform period of law in Indonesia, especially in the city of Jayapura continued to be improved law enforcement, especially in the field of land. The case of land rights issue either private ownership, legal entity or land in government facility there are many problems causing conflict and land disputes, thus disrupting the various activities of the people of Jayapura city. Pemalangan occurs because there is no settlement by customary deliberations.

In 2009, there were 15 cases that went to court in Jayapura. Land issues are submitted to the court for a permanent judgment, so that the parties take legal proceedings from the District Court, the High Court to the Supreme Court. Legal disputes over land can not be discharged in relation to the concept of the Unitary State of the Republic of Indonesia which is a Public-Oriented Legal State as explicit and implied in the 1945 Constitution of the Republic of Indonesia.

If we look closely at the judges 'ruling in handling adat civil disputes, there are two approaches that have so far colored the view of indigenous peoples' subjectivity, the evolutionist approach which holds that indigenous peoples are a community that has barriers in the integration process into the modern world so that this transition process must be guarded through legal procedures. while the other view is through pluralist pluralism which sees indigenous peoples as a diversity that must be maintained, so that indigenous peoples need to be guaranteed their basic rights independently to determine the choices for their respective community development. This second approach then emphasizes the importance of selfdetermination and the free prior and informed consent mechanism for any judgment which the Judge is about to pass in resolving disputes based on customary law.

Generally, the claim for customary land ownership is rejected by the Court based on several judgments examined or reviewed, the reason for the refusal is based on the judges' consideration because the plaintiffs can show the formal status of the claimed customary status of adat land, herein lies the judge's wisdom in understanding a legal matter faced with the meaning of the excavation of legal values living in the community, that the real ownership of customary land by indigenous peoples in a certain region or region does not have formal legal basis of ownership in the form of certificates or other formal evidence. The proof of ownership in general by habit that lives in the community is based on the testimony of the hereditary community into a habit that lives in the community. For example in the case of the Afar indigenous land dispute in Jayapura, which presents witnesses of Hans Ireeuw and witness Abner Meraudje explains that they know the disputed land is the customary land belonging to the Affar tribe but both base their knowledge on hearing and never see the letters land and know only that the land in 1974 was leveled to build housing; according to the consideration of the Panel of Judges that the Plaintiff is unable to show the evidence of the disputed customary land ownership to reinforce the principal argument that the object of the dispute is the Affar's customary land, so that the plaintiff's claim in the principal matter shall be rejected by the judge.

\section{III.CONCLUSION}

Based on the results of the above studies it can be concluded that; at the practical level there are two approach models used by judges to examine and adjudicate a civil case related to the values and rules of customary law in society, namely an evolutionist approach which holds the view that indigenous peoples are a community with barriers in the process of integration into the modern world, so that this transition process must be guarded through legal procedures. This view has an effect on the pattern of approaches used in dealing with a case related to customary issues and norms living in the community, this approach in view of the formalistic legal approach influenced by the possibility of legism-positivism, so that in some cases the disputed adat the right to customary land in Papu the judge always put forward formal proof of ownership of letters explaining proof of ownership of a plot of land, so that many customary civil cases must be rejected by the Court because the Plaintiff or the defendant can not prove formally proof of ownership over the disputed land.

While the other view is through pluralist pluralism that sees indigenous peoples as a diversity that must be maintained, so that indigenous peoples need to be guaranteed their basic rights independently to determine the options for the development of each indigenous community, so that the approach used by 
the judge in resolving a traditional dispute puts forward a sociological approach, rather than a formal legal approach. Several decisions that reflect this approach, thus maintaining and maintaining the existence of religious values and norms of customary law living in the community.

\section{REFERENCE}

1. Elizabeth Nurhaeni Butar-Butar, Civil Judge Freedom in Legal Invention and Antinomy in Application, Jurnal Mimbar Hukum, Vol. 23. No. 1, Februari 2011, FH. UGM, Yoyakarta, 2011, p. 62

2. Soekanto, Soerjono, Sociology An Introduction, Jakarta: PT. Rajagrafindo Persada, 2012, p. 9-11

3. Riduan Syahrani, The Principle of Civil Law, Cet.VI, Alumni, 2000, Bandung, p. 224

4. Riduan Syahrani, Ibid, 225)

5. Achmad Ali, Menguak Tabir Hukum, Gunung Agung, Jakarta, 2002, p. 49.

6. Basuki Rekso Wibowwo, The Role of Judges in Legal Reform, Paper presented at the Focus Group Discussion (FGD), related to Research on, The Meaning of Exploring and Following the Legal Values and the Sense of Justice that Live in the Middle of the Community in relation to the Authority of Judges to Examine and Resolve Civil Cases, at the Center for Legal Research and Indonesian Supreme Court Judiciary, Date. May 242016.

7. M. Hatta Ali, " The Role of the Chief Justice in Legal Discovery (Rechtsvinding) and Legal Creation (Rechtsschepping) in the Era of Reform and Transformation, Bunga Rampai Komisi Yudisial dan Reformasi Peradilan, Komisi Yudisial Republik Indonesia, Jakarta, 2007, h. 83-93. Compare this also with Komariah Emong Sapardjaja, Supreme Court Judge and Legal Invention (Rechtsvinding) in the Era of Legal Reform and Transformation", inside, Basuki Rekso Wibowo, Ibid

8. Basuki Rekso Wibowo, “The Role of Judges in Legal Development”, Op. cit., p. 62-73., Bandingkan dengan CA van Peursen, Strategi Kebudayaan, Kanisius, Jogjakarta, 1976., Edwin M Schur, Law and Society, Random House, New York, 1968. , Harry Bredemeier, "Law as an Integrative Mechanism", dalam Vilhelm Aubert eds, Sociology of Law, Penguins Books, Middlesex, 1973., Lawrence M Friedman, "On Legal Development", Rutgers Law Review, 1969, No. 1., Michael J Gerdhardt, The Power of Precedent, Oxford University Press, New York, 2008., Julie MacFarlane, Problem Solving, Cavendish Publishing Limited, London, 1996., Ofer Raban, Modern Legal Theory and Judicial Impartiality, The Glass House Press, Portland Oregon, USA, 2003. , Sharon Hanson, Legal Method and Reasoning, Second Edition, Cavendish Publishing Limited, Sydney, 2003., W. an Gerven, Kebijaksanaan Hakim, Erlangga, Jakarta, 1990., W. Pespoprodjo, Filsafat Moral : Kesusilaan Dalam Teori dan Praktek, Remaja Karya, Bandung, 1986., Yehezkel Dror, "Law and Social Change", dalam Joel B Grossman \& Mary H Grossman, Law and Change in Modern America, GoodYear Publishing Inc, Cal : 1971.

9. Abdul Manan, Reformasi Hukum Islam di Indonesia; Tinjauan dari Aspek Metodologis, Legislasi, dan Yurisprudensi, (Jakarta: RajaGrafindo, 2006), p. 156

10. Ibid, Achmad Ali, p.192

11. M. Syamsudin, Rekonstruksi Pola Pikir Hakim dalam Memutuskan Perkara Korupsi Berbasis Hukum Progresif, Jurnal Dinamika Hukum Vol. 11 No. 1 januari 2011.

12. Satjipto Rahardjo, Hukum Progresif Sebuah Sintesa Hukum Indonesia, Jogjakarta, Genta Publising, hlm. 137138.

13. Sugiri Permana, Paradigma Baru dalam Penyelesaian Sengketa Hak Asuh Anak Pada Peradilan Agama dalam http://badilag.mahkamahagung.go.id/ artikel/1302.html data diunduh pada Minggu, 9 Juni 2013. Dalam, Achmad Arief Budiman, Penemuan Hukum Dalam Putusan Mahkamah Agung Dan Relevansinya Bagi Pengembangan Hukum Islam Indonesia, Al-Ahkam, Jurnal Pemikiran Hukum Islam, Volume 24, Nomor 1, April 2014

14. Syamsuhadi Irsyad, Kapita Selekta Hukum Perdata Agama Pada Tingkat Kasasi, dalam Achmad Djunaeni, Putusan Pengadilan Agama dalam Yurisprudensi MA, MA RI, 2004, h. 20 dan 149.

15. Mahkamah Konstitusi RI (2010) Perkembangan Pengujian Perundang-undangan di Mahkamah Konstitusi. Jakarta Konstitusi Press, p. 41

16. Ibid

17. Ibid., p. 42

18. Ibid, p. 45

19. Mustafa Bola, dkk, Korelasi Putusan Hakim Tingkat Pertama, Tingkat Banding, dan Tingkat Kasasi (Suatu Studi Tentang Aliran Pemikiran Hukum, Hasaduddin Law Reviuw, Volume I, No. 1 April 2015.

20. Victor Imanuel W. Nalle, The Relevance Of Socio-Legal Studies In Legal Science, Mimbar Hukum Volume 27, Nomor 1, Februari 2015, p. 179-1

21. According to Balck Law Dictionary (Bryan Garnier, 2004, pp. 850) Judicial activism can be interpreted as a philosophy of judicial decision making where judges are allowed to use their personal knowledge of public policy, among various factors, to guide him to decide a problem. 